Ever present in the book is the promise microbial oceanographers place in environmental genomic sequencing. Researchers hope that this technique will lead to an "understanding [of] the genetic control of the physiology of the sea". One scientist interviewed puts forth the idea that one-third to one-half of microbial genomes might represent 'ecology genes' - genes that could explain the dynamics and interactions of organisms.

Scientists also discuss in the book how the ocean may operate as a network of genes, an increasingly popular perspective. The genenetwork concept is a helpful framework for considering interactions over long timescales. But if taken too literally, its value is less clear, especially over the shorter time frames of anthropogenic perturbations. It is a microbe's entire gene complement that shapes its overall physiology, response capabilities and interactions with other life forms - not just a single gene or gene set. Hence, simply probing the oceans for genes will not necessarily provide the organism- and genome-specific context probably needed to understand microbial dynamics.
Helmreich mentions the problem of deciphering meaning from the vast amounts of information being produced at increasingly rapid rates. This disconnection between information, inference and true function really is the 'elephant in the laboratory'. How do we move beyond gene sequences to understand cell physiology, functional roles, rates, activities, trophic linkages and global biogeochemical cycles?

As much as Alien Ocean captures the excitement and crucial nature of oceanographic research, the field still faces the grand challenge of advancing from sequence information to a functional understanding of the system. Although proper experimental design and a statistically appropriate depth of sequencing have yet to be achieved in marine metagenomic studies, there are more fundamental issues at hand. Many 'genes' sequenced in environmental metagenomic studies, or indeed in complete genome sequences of marine bacteria, archaea and unicellular eukaryotes, are still of unknown function. Stories are woven from those genes we can name, but other genes that might render insights into how a microbe wrangles with its environment remain untouched.

Gaps in our knowledge have led to raging disputes among microbiologists about whether common measures of microbial biodiversity reflect functional divergence. The state of the field is reminiscent of periods in medical research when inferences were made about the existence and roles of particular genes and molecules, such as the tumour suppressor p53, before concrete data were available. Reactions to such inferences propelled the field forwards. In the case of microbial oceanography, a tangible forward step would be to elucidate gene function and links to physiology. This would go a long way towards moving from sequence space to ecosystem-level understanding. Perhaps Alien Ocean will inspire the next generation to fulfil the promise of environmental genomic sequencing.

Alexandra Z. Worden and Darcy McRose are at the Monterey Bay Aquarium Research Institute, Moss Landing, California 95039, USA.

e-mail: azworden@mbari.org

\section{See Editorial, page 140.}

\title{
Ecology lost and found
}

\author{
Paradise Found: Nature in America at the \\ Time of Discovery \\ by Steve Nicholls \\ University of Chicago Press: 2009 \\ 536 pp. $\$ 30$
}

"We don't need history," I recently heard a
conservation scientist tell a group of students.
He was being provocative, targeting those ecol-
ogists who treat the past as a baseline to which
we should return. The world has changed too
much and is changing too fast, he argued,
for history to serve as a useful measure for
restoring nature. The questions that animate
conservation today do not ponder what we
have lost or how we can get it back. The past
is another world, and that world is gone. The
questions now are: what kind of world do we
want? And how can we create it?

In this context, Steve Nicholls's Paradise Found seems quaintly historical. The book is a cornucopia overflowing with the abundance of nature long gone. In this history, no species simply existed in the past. In early North America, Nicholls writes, "the fertile coasts teemed with fish and marine mammals ... prairies were a carpet of wildflowers" and the mountains were "clothed in forests".

This is history written as if the past were a spectacular nature documentary. This comes as little surprise when you learn that the author has been a producer of nature shows for television for the past 25 years, as he frequently reminds readers. The book even calls to mind historical re-enactments, as Nicholls asks his audience to imagine themselves with the eleventh-century Norsemen settlers in fabled Vinland; fishing for cod with the fifteenthcentury explorer John Cabot; or sitting under a tulip poplar as a flock of passenger pigeons burdens the boughs overhead.

Nicholls laments species that have been driven to extinction, but his real concern is a decline in the abundance of animals. By this he seems to mean wildlife spectacles that would be suitable for television. But Nicholls engages an important historical and ecological argument here, too. "An accurate picture of the past is important," he writes, as "a baseline to judge how effective conservation measures are."

A debate is raging among historians and ecologists regarding 'shifting baselines', a concept developed by marine biologist Daniel Pauly to describe how people often assess environmental decline only in the context of their own lifetimes. The sentiment is familiar:

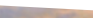

(2) 
no critical distance from his own paradisiacal tropes, nor any apparent awareness that these ideas also have a history that matters.

If paradise lies in the past, it logically follows that it is lost in the present. Similarly, what is missing in the present constituted paradise in the past. This is history as elegy, and makes Nicholls's stories about catastrophic crashes in wildlife populations sound like the same "inevitable trajectory" of decline. At one point, he even apologizes for the "all too familiar pattern".

The problem is that such stories are not all the same. Some species are so successful today that they are an ecological nuisance - for example, mute swans, zebra mussels and white-tailed deer. Population size is not everything: it depends on habitat. Humans take up a lot of habitat, but we have also created new habitats, and many small populations can survive just fine. To his credit, Nicholls does not hide these complications, but he doesn't make much of them either. This makes Paradise Found the kind of history that undermines itself on close reading: so much complexity spills out of this bounteous tome that the narrative cannot hold it.

And that points to a much bigger problem. There is no new historical narrative to replace the simplistic story of shifting baselines and paradise lost. As a result, many ecologists are simply abandoning history. This is not good: ecology is a historical science, and history is not just data for constructing a baseline for ecological models. It unpacks everything that goes into making the baselines and models themselves - ideas, scientific theories, social practices, industries, economies, ecological conditions and species that together shaped the environment at any given time in the past. Historical narratives also frame how we think about moving forward. So they must adjust to new information, open up new inquiries, force us to rethink data and question conventional wisdom.

In many places, we have only fragments of the abundant ecosystems that once existed, and only fragments of their history. The point is not to assemble those fragments as gospel, showing the way to a past to which we might return. The point is to put this history in conversation with ecological possibilities for the present and in the future. The devil, as they say, is in the details. And we might find some useful history there too, if we could just stop searching for paradise.

Jon Christensen is associate director of the Spatial History Project in the Bill Lane Center for the American West at Stanford University, California 94305-4225, USA.

e-mail: jonchristensen@stanford.edu

\section{The dangers of denying HIV}

\section{Denying AIDS: Conspiracy Theories, Pseudoscience, and Human Tragedy by Seth Kalichman Springer: 2009.205 pp. $\$ 25$}

Inadequate health policies in South Africa have reportedly led to some 330,000 unnecessary AIDS deaths and a spike in infant mortality, according to estimates by South African and US researchers. This carnage exceeds the death toll in Darfur, yet it has received far less attention. Seth Kalichman, a US clinical psychologist, shows in Denying AIDS how words can kill. His marvellous book should be read alongside Nicoli Nattrass's Mortal Combat, covering similar ground but from the perspective of a South African.

The tragic events in South Africa have been exacerbated by AIDS 'denialists' who, Kalichman alleges, assert that HIV is harmless and that antiretroviral drugs are toxic. The author discusses the psychology of denialism, which he says is "the outright rejection of science and medicine". He recounts the history of an HIV-infected US woman whose daughter died from an AIDS-related disease, and

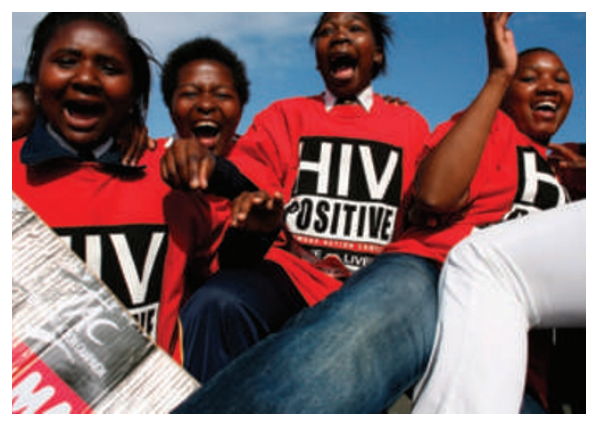

South Africa's high rate of HIV infection has spurred protesters to demand action to treat it.

who recently died herself, to demonstrate the downward path from "ordinary psychological denial to malignant denial to denialism". Kalichman dismisses denialists' attempts to portray themselves as intellectually honourable dissidents who question accepted wisdom. He draws clear distinctions between dissidence and denialism; the latter, he says, is merely a destructive attempt to undermine the science.

These attitudes are not unique to HIV. Denialism, notes Kalichman, is "partly an outgrowth of a more general anti-science and anti-medicine movement". Groups that support intelligent design, doubt global warming, claim that vaccines cause autism, argue that cigarettes are safe, believe that the terrorist attacks of 11 September 2001 were an intelligence-agency plot or deny the Holocaust all use similar tactics.

Kalichman asserts that influential groups within the AIDS denialist movement include academics, pushers of 'quack' cures and supportive journalists. He describes the academics involved as "deranged and disgruntled university professors who turn to pseudoscience as a platform to gain attention", noting that pseudoscience may include "sightings of UFOs, alien abductions, astrology, psychic predictions ... [and] outlandish claims about the cause and cure of diseases".

Kalichman describes how quacks, like some of the academics involved, misrepresent their qualifications to create an illusion of authority. One, he claims, treats AIDS with hyperthermia, massage, oxygen, music, colour, gem, aroma, hypnosis, light and magnetic fields, each word followed by "therapy". Another allegedly distributed a product in Zambia called Tetrasil, a pesticide used in swimming pools, until the Zambian government intervened. Kalichman concludes that "taking money from the poor for bogus treatments is beyond criminal" and castigates journalist supporters of the denialist viewpoint for neglecting their professional obligations to verify facts and avoid sensationalist stories. In a powerful ending, Kalichman claims that extreme right-wing politics influences the AIDS denialist movement.

Professional institutions continue to tolerate the conduct of academic denialists, despite the suffering that has resulted. The standard excuse for inaction has been freedom of expression - the First Amendment of the United States Constitution. But free speech has recognized limits, and causing death is one. In 2006, as Kalichman records, a group of concerned scientists and activists created a website, AIDSTruth (www.aidstruth.org), to provide evidence to counter the denialists' words. The international legal and human-rights communities should now investigate the deadly impact of AIDS denialism. Action might have widespread benefits: Paul Offit's tour de force, Autism's False Prophets, claims that pseudoscientists and quacks have used similar tactics to parasitize the suffering of desperate parents by persuading them that vaccines cause autism. As Kalichman says, denialism "will not break until the public is educated to differentiate science from pseudoscience, facts from fraud". John P. Moore is professor of microbiology and immunology at the Weill Medical College of Cornell University, New York 10021, USA. e-mail:.jpm2003@med.cornell.edu 